\title{
REVIEWS.
}

\section{THE MANAGEMENT OF THE PNEUMONIAS.}

By Professor J. G. M. Bullowa. Humphrey

Milford. Oxford University Press, 1937, 27/6 net.

The doctors fighting for the patient's life is a fine-sounding phrase, but the doctors may fight too hard. It conjures up a vision of eager and all too willing helpers, struggling to save a swimmer, who, unaided, would have reached the shore slowly, but unexhausted. But, it may be argued that he might not have reached the shore.

Thus it is with pneumonia. Who can be certain of the issue? Nevertheless, in spite of the mortality figures, the fact remains that the majority of cases of pneumonia recover without so-called specific treatment.

But what of the others? Can they not be saved, and can their sufferings not be mitigated and the course of the illness shortened and complications prevented? This is the case for specific serum therapy. Dr. Bullowa believes that by it these things can be achieved in appreciable measure. He stands four-square as its champion. He has no doubts, and this book packed with facts, figures and tables, illustrations and statistics, stored with a thousand useful details and instructions, (though not always presented as clearly as one might wish) is the logical outcome of this belief.

The indication for serum treatment, according to the author, is "any case of Pneumococcic pneumonia for which there is a specific serum." The reviewer does not conform to this belief or this practice. He believes that some pneumonia patients, like some swimmers, need special help, but not all; that by the routine use of serum in its present form, we may do as much harm as good, or worse than this. If we accept the thesis, however, let us see to what activities, to what labours, to what interference with the patient we are committed, if we follow such a faith in specific therapy to its logical conclusion.

Thirty-two distinct and distinguishable types of pneumococci are said to have been isolated and twenty-four different clinical types of the disease are described. The serum, to be effective, must be given early.
To give the appropriate serum early involves a quick and certain discovery of the true causative organism and the typing thereof. Here the difficulties begin, and on page 78 will be found pictorially represented some of the lines of attack on the patient. Sputum, if any, is obtained. If none, pharyngeal and laryngeal swabs are taken, the direct laryngoscope being advocated, or/and gastric lavage. "A blood culture should be taken in all patients with an acute respiratory infection. The blood culture should be repeated daily or oftener." (Page 59). To confirm the sputum typing, or in the absence of sputum, lung puncture and suction is advocated and has been performed in the author's clinic 2,500 times. "Its hazards are less than those of withholding necessary specific serum." (Page 97). On page 96 we read:- "The injection of the mouse peritoneum with sputum or broth is such a simple procedure that it may be entrusted to an interne, to the night superintendent or to a floor nurse trained for this task. If suitable peritoneal fluid has not been obtained or the mouse does not die while the day staff is on duty, arrangements should be made for a prompt autopsy of the mouse even at night and for implanting of heart's blood and brain into broth for incubation."

As adjuncts to the specific serum-therapy the oxygen tent is frequently employed and cupping is not despised. Daily enemas are given. When sedatives are ordered the patient is weighed "each day" in order to determine the dose. "Venoclysis" is frequently used and through the transparent rubber tubing of the apparatus all manner of substances are injected.

If severe collapse symptoms develop, the patient is suspended by the heels, head downwards (Page 300).

It is these things that seem to render the treatment suitable only to the hardiest races of mankind. When rest is so sorely needed, rest is denied. The endless pricks must be unendurable to many patients. The complexities of the typing, the mouse heart's blood, the mouse brain broth culture, the tenth day embryo chick chorion-allantoic membrane injections for the detection of viruses, the ophthalmic tests, the dermal reactions and so forth: all 
these things put the method outside the realm of practical medicine; at any rate, outside the walls of a well-equipped institution.

Though he cannot agree with the author, and though, if he had pneumonia, he would rather be treated by some shrewd general practitioner than by the methods advocated, nevertheless, the reviewer will give this book a place of honour on his shelves and read it again from cover to cover and go to it as a valuable book of reference. The work on specific serum-therapy must and will continue, but it is to be hoped that simpler methods and a less drastic technique will be evolved.

\section{HANDBOOK OF DIETS.}

\section{(Second Edition.)}

By Rose M. Simmonds, S.R.N. Dietitian'to the Hammersmith Hospital (Post-Graduate School), London County Council; . Late Dietitian to the London Hospital. With a foreword by LORD DAwSON OF PENN, P.C., G.C.V.O., K.C.B., M.D.(Lond.), Hon. F.R.C.S.(Eng.). William Heinemann, Ltd. 1937. Price 7/6 net.

Miss Simmonds' name is familiar not only to dietitians and to nurses in charge of diets, but to a large number of the medical profession as well, and a second edition of her handbook is welcome.

The book is clearly printed and well set out, and the general arrangement is good.

Starting with the constituents of a balanced diet, we go through all the necessary tables which are required if a suitable diet is to be prescribed quickly, and which are generally so difficult to find together, to the prescribing of diabetic diets.

One gramme of protein per kilogramme seems rather a meagre allowance, although it is the measurement usually taken; a man weighing 11 stone 11 lbs. would only get 75 grammes, but mention is made of the higher quantities required for children.

It seems unnecessary to quote twice in full the "Warning to diabetic patients taking insulin" and the "Care of the hypodermic syringe" as is done on pages 27 and 57 , and one of these might be cut out of further editions.

It is pleasant to see the glucose value of a general diet shown as 100 per cent. of the carbohydrate, 58 per cent. of the protein and 10 per cent. of the fat, as even quite experienced dietitians make mistakes here.

The book is very complete, and includes gastrostomy diets, low calcium diets (though these are not only used for the investigation of osteomalacia and Paget's disease), and low purin diets.

The last chapter is devoted to diets for infants and children in health and disease and some special recipes for them.

This book is the best of its sort that has been published for many a long day, and could only have been written by a dietitian familiar with every phase of her work, not only from the theoretical but from the practical aspect.

It deserves, and should have, its place on the shelf of every doctor in active practice.

\section{AN INTRODUCTION TO BACTERIOLOGICAL CHEMISTRY.}

By C. G. Anderson. E. \& S. Livingstone. Edinburgh. 1938. 10/6.

This small book is the first text-book on the chemical aspects of bacteriology which has appeared in this country. It is, therefore, to be welcomed as an attempt to supply a long felt want.

Those, who are engaged in the teaching of bacteriology to students of chemistry or other science students interested in the aspects of bacteriology which are independent of medicine, have had much difficulty in the past in finding any text-book which is really adequate for these students' requirements. The nearest approach to a suitable book is that produced by Buchanan and Fulmer, but this is much too big a book for any student who is merely taking a course in bacteriology as part of another degree and it contains a great deal of matter which has not got a very direct bearing on bacteriology.

It can safely be said that in its own field the book represents an advance on any text-book already existing. It is split up into three parts. There are five introductory chapters dealing principally with the phenomena in physical chemistry and biochemistry which have been found to be of special application in the study of bacteria, such as hydrogen on concentration, colloids and enzyme action. The 